\title{
The Implications of Village Regulation toward the Dualism of Local Leadership Dynamics
}

\author{
I Nyoman Subanda* \\ Universitas Pendidikan Nasional, Bali, Indonesia \\ I Nyoman Budiana ${ }^{* *}$ \\ Universitas Pendidikan Nasional, Bali, Indonesia \\ A.A.Ngr Eddy Supriyadinata Gorda ${ }^{* * *}$ \\ Universitas Pendidikan Nasional, Bali, Indonesia
}

Article Received: $13^{\text {th }}$ July 2019; Accepted: 22 ${ }^{\text {nd }}$ January 2020; Published: $31^{\text {st }}$ January 2020

\begin{abstract}
The transformation of local leadership in Bali has implications for the emergence of various phenomena regarding the relationship between the official administrative village and the customary village, both of which have their autonomous rights. The authority of desa adat (customary village) and desa dinas (official administrative village) coincides with each other. In this study, several issues will be discussed, namely: What is the model and process of transformation in local leadership especially in desa adat in Bali? What is the process and form of negaranisasi (the process of taking over a number of the state's roles and imitating the state in carrying out its duties) in local leadership especially in desa adat in Bali? What are the competencies and roles of local leaders in the local leadership process in Bali? What are the roots, causes, and solutions in handling horizontal conflicts in local leadership in Bali? Data were collected by interview, and documentation to obtain sufficient data variance and validity. The results of the study indicate that the synergy of two (2) types of local leadership is needed. The capacity and competence of village officials and prajuru adat (customary officials) are obliged to be enhanced, strengthened and empowered so that they are able to adapt in handling various problems that arise in rural communities in the era of modernization and globalization. For this reason, it is necessary to build a synergic relationship model and leadership coordination system between desa dinas and desa adat, a model for developing the capacity and competency of village officials and prajuru adat, and developing a model for handling conflicts that have been increasingly intense.
\end{abstract}

Keywords: Dualism; Local Leadership; Bali; Village; Autonomy.

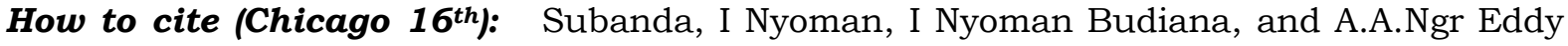
Supriyadinata Gorda. "The Implications of Village Regulation toward the Dualism of Local Leadership Dynamics." Udayana Journal of Law and Culture 4, no. 1 (2020): 39-61. https://doi.org/https://doi.org/ 10.24843/UJLC.2020.v04.i01.p03 .

doi: https://doi.org/10.24843/UJLC.2020.v04.i01.p03

\footnotetext{
${ }^{* *}$ Email/Corresponding Author: subanda.nyoman@yahoo.co.id

** Email :. budiana@undiknas.ac.id

${ }^{* * *}$ Email: eddysupriyadinata@undiknas.ac.id
} 


\section{Introduction}

\subsection{Background}

Village government organizations with a fairly strong leadership pattern existed before the arrival of Dutch colonialism in Indonesia. However, ther exact time when the local leadership developed along with its path is remaining unknown. ${ }^{1}$

There is a lack of written evidence, mainly in the form of inscriptions, that was found in the era of Hindu kingdoms in Java and Bali. ${ }^{2}$ For the situation in Java, Casparis revealed the existence of two stages of local leadership development, namely, the development around the $10^{\text {th }}$ century and earlier, as well as the development in the Majapahit era and beyond.

In the development of the $10^{\text {th }}$ century and before, there was no local leader (village head) as an individual figure, but there was always the Council of Leaders called Rama. On that basis, the decisions concerning the policies of the village government were also taken together, because the rural community more displayed a figure with an autonomous institution, so the Casparis likened it to the Village Republic. ${ }^{3}$

After the $10^{\text {th }}$ century, there was a process leading to a centralized system of power by the central government. Local government (in this case, the village), was previously quite democratic, in which the village leader was in the hand of the village's oldest council began to be directed at the sole power of a figure. In the era of the Majapahit kingdom, this shift began to appear with the appearance of a single village leader called buyut or the great-grandfather, who was also an extension power of the central government, namely the ruling kings. ${ }^{4}$

The leadership situation stated above was still valid and increasingly complex in the days of Dutch colonial rule. ${ }^{5}$ The Dutch controls' seemed to continue the existing system. The Dutch strengthening the position of the village government, in representing the central government, to secure its agricultural products as the export commodities.

The Dutch path was continued by Japan in the era of the Second World War. The fact was that Japan did not interfere with the traditional government affairs, but it massively utilized the existing traditional

1 Gede Widja. Dualisme Kepemimpinan Lokal pada Desa-Desa Pegunungan di Kabuapaten Buleleng dan Implikasinya dalam Pembangunan Nasional (Singaraja: Laporan Penelitian STKIP Singaraja, 1994), 6.

${ }^{2}$ Casparis, J.G. The Evolution of The Socio Economic, Status of Javanese Village and Its Inhabitan, (in Sartono Kartodirja (ed). Paper of The Forth Indonesian-Dutch History Conference (Agrarian History) (Yogyakarta: Gadjah Mada University Press, 1986). 3-24.

${ }^{3}$ Ibid.

${ }^{4}$ Ibid.

5 Clifford Geertz. The Theatre State in Nineteenth Bali, translated by Hartono Hadikusumo. Negara Teater Kerajaan-Kerajaan di Bali Abad XlX. (Yogyakarta: Yayasan Banteng Budaya, 2000),45-85. 
leadership and provided a position that prioritizing official village leadership to support the interests of the Japanese government.

The transformation of the dualism of local leadership existing in Bali had occurred in the period before the colonial era, Orde Lama or the Old Order period, Orde Baru (the New Order) period up to Orde Reformasi (the Reformation Period) that has been taken place nowadays. Before the reformation period, the position of desa adat (the customary village) was sub-ordinate to desa dinas (the official administrative village). Actually, these two villages have different functions. Desa adat has functions in the field of culture, customs, and ritual traditions of Hindu religious life, while desa dinas plays its functions and roles in the field of bureaucracy in the level of official village, runs administrative roles, and becomes the part of regional government structure. ${ }^{6}$

In fact, nowadays customary villages have very strong bargaining positions both in the supra-local government and in the village government. Recognition of customary villages is regulated in Article 18B paragraph (2) of the 1945 Constitution of the Republic of Indonesia. Customary villages are seen as local government structures that have the duty to keep the custom and culture. The customary villages' bargaining positions then becomes stronger in the context of strengthening village autonomy to the regions. It entails that the relationship between customary villages and official administrative village equally strong, in which both have autonomous rights, and at the same time carry out almost coincided responsibilities.

Changing policies of the national government were affected by the autonomy of village governments and their claims on customary, and communal property. ${ }^{7}$ Strengthening the existence of customary villages is recognized as part of a democratic framework in which the central government respects the unity of customary law that still exists and develops in Indonesia. In Bali, the regional autonomy regime has changed the political structures of the province. Bali's eight districts and a municipality are now able to exercise strong authority to manage their own territory. ${ }^{8}$ The existence of the customary villages in Bali is still very strong. Various religious ceremonies, livelihood activities and cultural preservation involve customary villages. Every Balinese living on the island of Bali must become a member of adat (custom).

6I Nyoman Nurjaya, "Sustainable Cultural Development: The Future Of Balinesse Adat Village Posterior The Enactment Of Law Number 6 Year 2014 Concerning Village", Jurnal Jatiswara, 33, no. 1(2018): 7.

7 Jacqueline AC Vel, and Adriaan W. Bedner. "Decentralisation and village governance in Indonesia: the return to the nagari and the 2014 Village Law." The Journal of Legal Pluralism and Unofficial Law 47, no. 3 (2015):496.

${ }^{8}$ Agung Wardana, "Debating spatial governance in the pluralistic institutional and legal setting of Bali." The Asia Pacific Journal of Anthropology 16, no. 2 (2015): 109. 
The dualistic system of local leadership and nuances of central government intervention in village leadership continue until the issuance of Law Number 6 of 2014 concerning the Village Government. This law reflects government interference in uniforming villages throughout Indonesia. The enthusiasm of various customary community groups or village-like communities in all regions of Indonesia experienced very profound and fundamental changes.

Although the government carried out a process of uniformity and standardization of local leadership, in de jure, Law Number 6 of 2014 concerning Village Government still seems to provide an opportunity for the existence of customary government institutions (outside the official village government) to exist and be maintained in the lives of village communities. Based on the de jure explanation above, it seems that the dualism of local leadership at the village level in Indonesia is indeed given to grow and develop according to the demands and characteristics of the local community. The consequence of the dualism of local leadership gave rise to a variety of local leadership in Bali. There are several variations of government found in Bali which are the implications of the negaranisasi (the process of taking over a number of the state's roles and imitating the state in carrying out its duties) of local leadership, namely; first, in an official administrative village area consists of a customary village area; second, in an official administrative village area consists of several customary villages; third, several official administrative village areas are located in one customary village area; fourth, in an official administrative village, consists of several customary villages and some from another village.

After the fall of Orde Baru, every region including Bali repositioned the central government. In Bali, a concrete step taken was to bring up the discourse of Ajeg Bali (preserve, create, and develop Balinese culture) which sets the customary village as a foundation of hope for doing ideological revival. Being made a customary village as a foundation of hope and at the same time as an idol of the Balinese community was finally responded by the provincial government of Bali. The provincial government of Bali giving more authority to the customary villages and at the same time giving economic concessions in the form of 250 million assistance to each customary village in Bali and a motorbike to all kelian (leader or head) of customary villages in Bali. More authority and economic concessions given by the supra-local government to the customary villages were finally followed by the regencies and city government in Bali.

The great authority and attention are given by the supra-local government to the customary villages lately often make them take over various state roles. Giving investment permits, controlling the population, regulating traffic order, and managing tourism destinations in the villages are some examples of the role of customary villages that have taken a 
number of state roles. Pecalang as a traditional village equipment tool that originally played a role only around security in the implementation of customs now has more role as a state apparatus. Regulating traffic, curbing the urban population, maintaining and participating in securing political party congresses are a number of concrete examples of the role of the state taken by pecalang. This is reaffirmed by Ardana, that pecalang has a very important role, even becoming a permanent security section in every banjar (the smallest form of local government in Bali) or desa adat activities such as securing the marriage and funeral ceremony, flood, fires, hurricanes and even traffic jams. ${ }^{9}$

\subsection{Purpose/Research Problem}

This research focuses on the phenomena of the dualism of local leadership in Bali that addresses 4 questions, namely 1) What is the model and process of transformation in local leadership, especially in customary villages in Bali? 2) What is the process and form of negotiation in local leadership, especially in customary villages in Bali? 3) What are the competencies and roles of local leaders in the local leadership process in Bali? 4) What are the roots of the problem, causes and solutions to handling horizontal conflicts in local leadership in Bali?

\subsection{Method/Research Outline}

This study uses a descriptive qualitative approach with some data collection techniques: (1) observation, (2) in-depth interviews, (3) reviewing journal research documents that are relevant to this study. In qualitative descriptive research, the focus of researchers is to explore actual phenomena, and the nature of the data collected is more natural with rational analytical. 10

The study was conducted in Pedawa Village, Banjar District, Buleleng Regency, Bali Province, Indonesia. Informants at the location of this study consisted of the Village Chief Pedawa, Kelian Adat (indigenous leaders) Pedawa Village, Former Secretary, Former Kelian Adat Village, Former Kelian Dusun Insakan, and local community leaders. The research was also conducted in Dalung Village, North Kuta District, Badung Regency, Bali Province, Indonesia. Informants at the location of this study were the Dalung Village Chief, Village Secretary, Kelian Adat Dalung Village, Moslem, and Christian community leaders. In addition to informants from the two villages, this study also used observer informants and indigenous researchers. They function as peer debriefing. The selection of research

9 I Gusti GedeArdana. Pemberdayaan Kearifan Lokal Masyarakat Bali dalam Menghadapi Budaya Global (Denpasar: Pustaka Tarukan Agung, 2007), 87-88. 57.

10 Burhan Ashsofa. Metode Penelitian Hukum, cet ke-3 (Jakarta: Rineka Cipta, 2001), 
locations is based on the consideration that Pedawa Village is a homogeneous village whose entire population is Hindu. This village is an ancient village in Bali. In contrast, the Dalung village is a heterogeneous, multi-ethnic, multi-religious village (Hinduism, Islam, Christianity, Buddhism), and even Balinese who are Christian (generally Balinese are Hindu).

Data analysis in this study was carried out qualitatively, interactively and take place continuously to completion so that the data becomes saturated. Data analysis was carried out in various steps as follows: (a) Data reduction, data obtained from the results of field research are contained in a complete and detailed description or report. Data were collected from field research conducted at the study site and various literature used in this study. The data was then reduced, summarized, selected for the main points, focused on the important things through the editing process. This reduction was carried out continuously during the research carried out, (b) Presentation of data, the purpose is to make it easier to see the overall picture or certain parts of the research results. This section is the process of organizing data into a specific form to show parts in full, (c) Drawing conclusions, the verification was carried out continuously during the research carried out, this section attempts to analyze and search for data collected through the process of looking for patterns, themes, similar relationships, other things that often arise, which are stated in conclusions that are still tentative leading to fundamental conclusions.

\subsection{Theoretical Framework/Literature Review}

Villages or other names have existed before the Unitary State of the Republic of Indonesia was formed. As proof of its existence, Explanation of Article 18 of the 1945 Constitution of the Republic of Indonesia (before the amendment) states that "Within the territory of Indonesia, there are approximately 250 "Zelfbesturende landschappen" (indigenous government which gained its autonomy because of a number of agreements with the Dutch East Indies Colonial Government) and"Volksgemeenschappen"(customary village), such as desa in Java and Bali, Nagari in Minangkabau, dusun and marga (clans) in Palembang, and so on. These areas have an original structure and can, therefore, be considered as special areas. The Republic of Indonesia respects the position of these special regions and all state regulations concerning these regions will remember the rights of the origin of the region". Therefore, its existence must still be recognized and given a guarantee of its survival in the Unitary State of the Republic of Indonesia ${ }^{11}$

\footnotetext{
${ }^{11}$ Explanation of Law Number 6 of 2014 concerning Villages.
} 
The normative provisions regarding villages in Indonesia are regulated in Law Number 6 of 2014 concerning Villages. ${ }^{12}$ This law was prepared in the spirit of applying the constitutional mandate, namely the regulation of customary law communities in accordance with the provisions of Article 18B paragraph (2) to be regulated in a government structure in accordance with the provisions of Article 18 paragraph (7). Nevertheless, the authority of the customary law community unit regarding the regulation of customary rights refers to the provisions of relevant sectoral legislation. With the construction of combining the function of the self-governing community with local selfgovernment, it is hoped that the customary law community unit which has been part of the village area, has been arranged in such a way as a village and customary village.

The village refers to a term that is closely related to the control of the area by a group of people who have certain functions. Villages as a place for community organizations have different terms. Article 6 of Law Number 6 Year 2014 concerning Villages affirms (1) Village consists of Customary Villages and Villages. (2) The mention of Desa or Desa Adat as referred to in paragraph (1) is adjusted to the mention applying in the local area. In Balinese culture, there is a dualism of villages, namely desa adat or customary village and desa dinas or official administrative village. The official administrative village has the authority to regulate matters of state administration and the customary village refers more to matters of a religious and cultural nature. ${ }^{13}$ I Dewa Gede Atmadja then explained that the term village in Bali contained 2 (two) meanings, namely:

(1) Desa Adat or Customary Village, a regional unit whose residents are jointly responsible (krama desa or villagers) conduct worship, with the intention of maintaining the purity of village land (grondmagis), as well as maintaining temples in a village.

(2) Desa Dinas or Official Administrative Village, a territory (regional) government. So it was formed by the Government, and by Law the Regional Government was given the label "autonomous village." 14

The customary village has an identity as a communion element of customary law community, as well as having some of the characteristics

12 Before the enactment of Law Number 6 of 2014, Indonesia already had Law Number 5 of 1979 concerning Village Government established by the Government in the New Order Era. Both of these provisions have differences in legal politics.

${ }^{13}$ Satrya, I. Ketut Teguh Yudha, et al. "Sinergi Desa Adat fan Desa Dinas falam Pengelolaan Aset Desa Untuk Mewujudkan Harmonisasi (Studi Pada Desa Adat Dan Desa Dinas SambangaN)." JIMAT (Jurnal Imiah Mahasiswa Akuntansi) Undiksha 7, no. 1 (2017).

${ }^{14}$ I Dewa Gede Atmadja. Awig-Awig desa adat suatu analisis hukum tata negara, Revitalisasi Awig-Awig Desa Adat (Denpasar: Fakultas Hukum Universitas Udayana 2005), 9 . 
The Implications of Village Regulation toward the Dualism of Local Leadership Dynamics

I Nyoman Subanda, I Nyoman Budiana and A.A.Ngr Eddy Supriyadinata Gorda

that distinguish them from other social groups. ${ }^{15}$ Customary village is a community unit where a sense of unity as a traditional village citizen is bound by karang desa or a certain area with clear boundaries and is also bound by a system of prayer places called kahyangan tiga consisting of Pura Desa, Pura Puseh, Pura Dalem (three main temples in each village area in Bali). In a customary village, of course, it has customary rules that regulate community order in the area of the customary village. ${ }^{16}$ The existence of official villages depends on the will of the government, while the customary village is traditional institution from the community itself as an embodiment of customary institutions, which in relation to the government are led by customary leaders to actively participate in the implementation of government working programs that are channeled through the official administrative village. ${ }^{17}$

The official administrative village and customary village in Bali are generally in a harmonious condition and there is a communication relationship between the elements of the official village and customary village in the structure of the government structure. The harmony of the official administrative village and customary village gave rise to the expression "one body of two heads". In the relationship between the customary village and the official administrative village, it is necessary to watch out for the hegemony of customary village by state power personified by the official administrative village (kelurahan) as an extension of the state's hand. 18

\section{Results and Discussion}

\subsection{The dualism of Local Leadership in Bali}

The existence of dualism in village governance in Bali has become a distinctive characteristic and uniqueness in Bali. The existence of customary villages, also called desa adat, is a customary government that has been around for generations. The existence of this customary village continues even though in the government system of the Unitary State of the Republic of Indonesia, there are official administrative villages, as the smallest government scope in the country. Even, with the rapid globalization driven by the rapid growth of the tourism industry, it is unable to eradicate the

15 Sukawati Lanang Perbawa, "The Implications of Act no. 6 Year 2014 on The Village Existence of Adat Village in Bali1." International Journal of Research in Social Sciences 6, no. 2 (2016): 122-140.

16 I Dewa Herman Yudiawan, "Pendapatan Desa Adat: Kontruksi Hukum Pungutan Untuk Mewujudkan Bebas Pungutan Liar." Jurnal Magister Hukum Udayana (Udayana Master Law Journal) 8, no. 2 (2019): 249-260. Post, 30.

17I Wayan Surpha. (2002). Seputar Desa Pakraman dan adat Bali. Denpasar: Bali

18I Gusti Ketut Arya Sunu. "Harmonisasi, Integrasi Desa Pakraman dengan Desa Dinas yang Multietnik dan Multiagama Menghadapi Pergeseran, Pelestarian, dan Konflik di Bali." Jurnal Imu Sosial dan Humaniora 3, no. 2 (2014): 456. 
existence of customary villages in Bali. They remain because they are related to the needs of the Hindu community in Bali in carrying out their spiritual and social life. The dualism of the village in Bali can be illustrated in the following figure:

Chart 1 Village in Bali

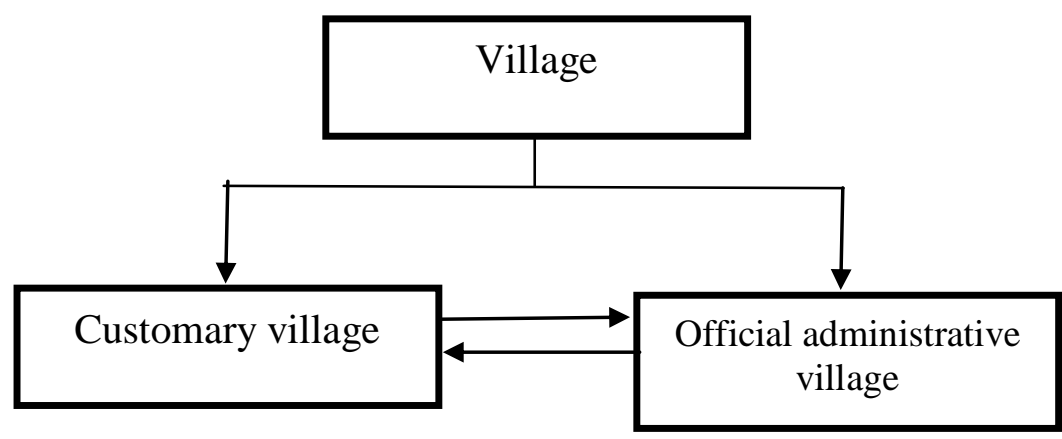

The dualism of the village government is actually no longer known in the Indonesian national legal system. This is because both in Law Number 6 of 2014 concerning Villages and Law Number 23 of 2014 concerning Regional Government do not distinguish the definitions of customary and official administrative villages. In both laws, the existence of villages, both official and customary villages, are defined as the legal community units that have territorial limits authorized to regulate and manage government affairs, the interests of local communities based on community initiatives, origin rights, and / or traditional rights which are recognized and respected in the system of government of the Unitary State of the Republic of Indonesia. These provisions can lead to multiple interpretations of the understanding of autonomy possessed by each type of village, it can even produce its own polemic for Balinese people given the different principles between these types of the village.

For Balinese people who are accustomed to the dualism of the village, in their perspective, the official village is an administrative village whose duties and authorities are related to the government. While the customary village is a community unit that has existed for a long time from generation to generation and is subject to customary law that has been mutually agreed upon. The customary village is not a government institution that submits to its superior government as an official administrative village. The implementation of authority based on original rights and authority on a local scale customary village is regulated and managed by the customary village by observing the principle of diversity. ${ }^{19}$

19 Mulyanto, "Keberlakuan UU No. 6 Tahun 2014 Tentang Desa di Bali dalam Perspektif Sosiologi Hukum." Mimbar Hukum-Fakultas Hukum Universitas Gadjah Mada 27, no. 3 (2015): 418-431, 425. 
The legal change movement in Indonesia by using legal pluralism as a foothold has gone far enough. One of them is the recognition of the rights of customary people, including the law in the constitution. 20 In the constitution, the existence of customary villages is recognized as stated in Article 18B Paragraph (2) of the 1945 Constitution which states that "The State recognizes and respects customary law community units along with their traditional rights insofar as they are alive and in accordance with the development of society and the principle of the Unitary Republic of Indonesia, which is regulated in law".

Recognition of the existence of customary people as part of the State of Indonesia has been stated in various laws and regulations. The recognitions are seen by the presence of phrases that mention "customary law communities" in the relevant laws and regulations, along with the forms of involvement. Nevertheless, there are two things that need to be noted, namely: first, the recognition is still partial or sectoral, meaning that the recognition is only limited to certain sectors depending on the aspects regulated by the relevant laws and regulations; second, acknowledgments contained in the laws and regulations are still abstract and universal, meaning that to get recognition that is concrete-individual in nature it still needs to be determined by more specific norms. ${ }^{21}$

There is a dualism of the village in Bali even though it has existed since the Dutch colonial era which was regulated in legislation. However, until now dualism of the village in Bali has not been able to explain the position of customary villages with official administrative villages or between customary villages with supra-local governments. The perpetuation of village dualism does not have to be interpreted that there is no conflict between them, because the data shows that the dualism of the village results in confusion and overlapping of the village in carrying out its functions. There are various activities that should be carried out by official administrative villages, but the fact is that customary villages participate in providing assistance in official activities.

According to Sunggono, the failure in implementing a policy can occur if in the context of the implementing structure, because of various problems related to the unclear division of authority and responsibility as well as the scope of tasks to be done. ${ }^{22}$ For example related to the problem of structuring the population, controlling pedagang kaki lima or the street traders, urban arrangement and other administrative matters. In addition,

${ }^{20}$ Muhammad A. Rauf. "Politik Hukum Pembentukan Desa Adat dalam Sistem Pemerintahan di Indonesia." De Lega Lata 1, no 2 (2016): 422.

${ }^{21}$ FahmiArisandi. "Peran Strategis Pemerintah Daerah dalam Mengakui Masyarakat Hukum Adat." Jurnal Surya Keadilan: Jurnal Ilmiah Nasional Terbitan Berkala Fakultas Hukum Universitas Muhammadiyah Bengkulu 2, no. 1 (2018): 271-272. 149-153.

${ }^{22}$ Sunggono, B. Hukum dan Kebijaksanaan Publik. (Jakarta: Sinar Grafika, 1994), 
pecalang also takes part in security matters outside of customary related activities, such as securing official inauguration, music event music, and others. This dualism then produces a variety of opinions in the community that can be elaborated into 4 (four) important points that must be studied, namely:

1. Desiring that the atmosphere of village life in Bali be left as it is. The official administrative village has the duty to take care of matters relating to government administration and development issues. Meanwhile, the customary village handles matters relating to the implementation of Balinese customs and Hinduism. If there are obstacles in the implementation of tasks, the official administrative village will usually ask for assistance from the customary villages and leaders to resolve them.

2. Desiring that the official administrative village be deleted and all matters at the village level are left to the customary village. This opinion arose as a reaction to disagreement over the domination of the official administrative village against customary villages in the Bali region. The customary villages whose existence has taken root and become the lifeorder of the Balinese people are taken away and their role was aside by the official administrative village.

3. Desiring that the two types of villages may be maintained and live side by side like a married couple. Note that there is a clear division between the two villages, especially those relating to the authority and budget provided for each village. Thus, it is expected that there will not be an impression that the existence of official administrative villages is preferred over the customary villages.

4. Desiring that there is only one type of village in Bali area, namely the customary village led by Bendesa Adat or the customary leader. The customary village equipment is then divided into 2 (two) fields, namely the religious and customary fields, as well as the administrative sector, like Nagari in the Minangkabau of West Sumatra. Thus, the dualism of the village can be eliminated, and the existence of customary villages will take over all the tasks that have been carried out by the official administrative village in which prajuru desa adat or the officials of the customary village who handle the field of government administration.

\subsection{Negaranisasi of The Customary Village}

Negaranisasi (the process of taking over a number of the state's roles and imitating the state in carrying out its duties) is one of the things that cannot be denied from rural conditions in Indonesia today. In addition to changes in the rules of the village government, the state programs that enter the village are very diverse. Negaranisasi in the context of traditional leadership that occurs in customary villages in Bali, apart from state 
intervention, is also due to the influence of globalization. Globalization in the context of this research is interpreted as a form of interaction between Balinese people who are also the customary people and local, regional, or international outside parties. The era of globalization is the reason for the revival of cultural identity and local wisdom in various parts of the world. ${ }^{23}$ Customary villages have a responsibility in facing multicultural communities and the development of a stream of modernization that enters traditional villages. It means that the paradigm changes that occur in the customary people are influenced by external influences that come from other villages in the same regency, other villages outside the regency, the village concerned and communities in other provinces to the international community. ${ }^{24}$

In the interactions that are influenced by globalization as described above, it has a broad and fundamental impact on the identity of customary villagers. The changes in self-identity have further implications for the orientation of the community or krama (villagers). With the ease of communication and the breadth of the environment of the village association, they allow krama desa or villagers to affiliate with various organizations centered outside the village so that the activities and social interactions carried out are often carried out with parties or people outside the village. The social activities that have been carried out with communities in customary villages often shift to social activities involving parties outside the village. As a concrete example of the shifting pattern of religious rituals such as Ngaben masal (collective funeral ceremony), metatah (cutting teeth ceremony) which were previously done with fellow villagers, are now commonly done with various religious organizations, klen or soroh (clans) in which the religious ritual activities are carried out outside the village. In addition to these examples, it can also be seen that there has been a plurality of ethnic populations including the plurality of citizens, and the attraction between the interests of investors and the interests of the people of Bali. 25

Based on the description above, the process of negaranisasi of the customary village actually does not always come because of natural intentions or processes but also because of government intervention in customary village leadership. The inclusion of customary village interventions against local entities or communities in Bali includes traditional customary village communities, in addition to the desire of the

${ }^{23}$ Anak Agung Gede Oka Wisnumurti, and I. Wayan Rideng. "The Development of Bali Tourism Through Cultural and Local Wishdom of Pakraman Village." Journal of Tourismology 3, no. 2 (2017): 38-43.

${ }^{24}$ Interview with Gede Widja, Anthropologist from Undiksha Singaraja, April 16, 2019.

25 I Gusti Ngurah Gorda. Manajemen dan Kepemimpinan Desa Adat di Propinsi Bali. (Denpasar: Widya Kriya Gematama,1999), 15. 
government to be able to control customary villages also because of the space provided by the customary peoples. This means that the strengthening of state domination in customary villages seems relevant because the customary people accept well even carry out happily.

\subsection{Competence and Role of Local Leaders}

The existence of a customary village in Bali is normatively regulated in the Regional Regulation of the Province of Bali Number 4 of 2019 concerning Customary Villages in Bali. According to Article 1 number 8, Customary Villages is a unit of customary law community in Bali which has territory, position, original arrangement, traditional rights, own assets, traditions, the social order of community life for generations in the bond of a holy place (kahyangan tiga or kahyangan desa). The duties and authorities and the right to regulate and manage their own households. The Customary Village is a legal subject in the system of governance in Bali Province. The Customary Village is a Government unit that is managed by Indigenous people and has the right to take care of the area and life of the community in the customary village environment. ${ }^{26}$

In the discourse of adat in Bali, it seems that adat emerges as a uniform entity. In fact, adat has diverse characteristics, as in the community described here; claiming as the truly indigenous people of Bali island, Bali Aga, Bali Mula or Bali Pegunungan.27 There are several types of customary village management structures in Bali, namely the hulu apad structure model which is better known in customary villages categorized into Bali Age villages whose positions are in the mountainous areas or in very small highland areas affected by Majapahit. The management structure of customary villages with the hulu apad system prioritizes the role of leaders of their seniority in the customary people, both in terms of age and marital status. From the educational status, mostly the leaders of this system do not have a high formal education level, which is senior high school level and below, and some of them cannot even read and write. This is very different from the customary village without hulu apad management structure located in the lowlands. The customary village leaders tend to be influenced by Majapahit in which the way of determining the management or leader is a by-election, even though there are still some them using offspring and their educational status is relatively higher.

By paying attention to the competencies possessed by the customary village structure using the hulu apad system, it is found that there are no

26 Putu Sugiantiningsih, I. Made Weni, and Tommy Hariyanto. "Effect of Bali Province Regional Regulation Number 4 of 2019 on Pecalang Organizations in Bali." International Journal of Multicultural and Multireligious Understanding 6, no. 3 (2019): 728-734.

27 I. Wayan Suyadnya, "Self-Identification and Repositioning of the Tengananese in the Discourse of Adat Community in Bali." Masyarakat: Jurnal Sosiologi (2019): 27-51. 
significant problems in the management of their villages. It means that all their tasks can be done properly such as carrying out related duties and responsibilities in the implementation of customs and religious rituals. Village activities that have nuances of customs and habits are routine village activities in accordance with the customary calendar applying in the village carried out with the concept of togetherness of the leaders and village communities by prioritizing the spirit of consensus and harmony known as the gilik saguluk, paras paros sarpana ya, salunglung sabhayantaka. With such enthusiasm, the problem of the level of education possessed by village administrators is not significant in driving the implementation of customs and culture that live and develop in a village.

The limitations of the capacity and competence of prajuru desa adat or the customary village officials are only felt, when dealing with outside parties, such as resolving disputes with other villages, having dialogue or discussing with the researchers or discussing with supra-local governments, and giving explanations to students, tourists and observers of various social problems that come to the village concerned. From a number of villages studied, it can be stated that customary villages in Bali have a high intensity in interaction with outsiders such as the number of guests as researchers, students and of course the most guests are tourists, both domestic and foreign, regardless whether these customary villages are the tourist destination or not.

The high intensity of prajuru desa adat interaction with outside parties, requires the customary village apparatus or instructors to enter a dialogue, discuss and provide explanations related to the potential and uniqueness of the village they have. Therefore, there is a need for skills to convey information to stakeholders based on experience, insights, and knowledge that must be possessed by every customary village instructor. Communication skills and the ability to solve problems faced both in the internal and external contexts of the village in the present era, such as the complexity of marital, inheritance, land and community affairs issues related to beliefs, and others, demand all prajuru desa adat improve their capacity and competence so that the various functions and responsibilities of traditional villages can be handled as well as possible. On the other hand, according to Nugroho, to achieve leadership goals in the community, a local resource approach is needed, namely using a communication model that places individuals to actively participate in each momentum of activity in the community itself. 28

${ }^{28}$ Riant Nugroho, Otonomi Daerah: Desentralisasi Tanpa Revolusi; Kajian Dan Kritik Atas Kebijakan Desentralisasi di Indonesia. (Jakarta: Elex Media Komputindo, 2004). 


\subsection{Potential Conflict in the Dualism of Village in Bali}

The intensity of the customary conflict in Bali has been said to increase in the last decade, both in terms of quantity and quality. The increase in quality and conflict can be proven by the existence of a number of facts reported by mass media including the cases of the villages of Semana, Tegallalang, Keramas, Bangli, Kemoning Klungkung, Pangkung Karung, Buleleng and so on. Conflicts between residents and traditional villages, for example, are motivated by the decision of officials in the official administrative village that do not use village funds to improve traditional facilities. This decision was considered as an individual decision which eventually turned into a conflict between customary villages and individuals. ${ }^{29}$

The intensity of the conflict with the nuances of customary villages in Bali still continues even with the intensity up to physical clashes. Physical clashes that have occurred in the conflict of customary villages include the expulsion of residents from the village concerned, burning houses, and physical abuse. This condition has implications for the problem of official administrative in the village. From the various cases, there were even cases of customary villages with residents that could not be resolved by the local government, so they had to proceed to the court level. Below is presented data on various conflict cases in several regencies in Bali.

Table 1 Conflict cases in several regencies in Bali

\begin{tabular}{|c|c|c|c|c|}
\hline No & $\begin{array}{l}\text { Conflict } \\
\text { Area }\end{array}$ & $\begin{array}{l}\text { Villages in } \\
\text { conflict }\end{array}$ & $\begin{array}{l}\text { Conflict } \\
\text { Intensity }\end{array}$ & Conflict resolution \\
\hline \multirow{5}{*}{1} & \multirow{5}{*}{$\begin{array}{l}\text { Buleleng } \\
\text { Regency }\end{array}$} & $\begin{array}{l}\text { Desa } \\
\text { Mekarsari }\end{array}$ & Social tension & \multirow{4}{*}{$\begin{array}{l}\text { Dialogue is facilitated by } \\
\text { the Regional Government } \\
\text { of Buleleng }\end{array}$} \\
\hline & & $\begin{array}{l}\text { Desa } \\
\text { Sambangan }\end{array}$ & $\begin{array}{l}\text { Expulsion of } \\
\text { residents }\end{array}$ & \\
\hline & & $\begin{array}{l}\text { Desa Giri } \\
\text { Mas }\end{array}$ & $\begin{array}{l}\text { Regional } \\
\text { blockade }\end{array}$ & \\
\hline & & Desa Sudaji & Social tension & \\
\hline & & $\begin{array}{l}\text { Desa } \\
\text { Temukih }\end{array}$ & $\begin{array}{lr}\text { Physical } & \\
\text { clashes } & \text { and } \\
\text { expulsion } & \text { of } \\
\text { residents } & \\
\end{array}$ & $\begin{array}{l}\text { Settlement to the high } \\
\text { court level }\end{array}$ \\
\hline \multirow{3}{*}{2} & \multirow{3}{*}{$\begin{array}{l}\text { Klungkung } \\
\text { Regency }\end{array}$} & Desa Sulang & $\begin{array}{l}\text { Expulsion of } \\
\text { residents }\end{array}$ & \multirow{3}{*}{$\begin{array}{l}\text { Dialogue is facilitated by } \\
\text { the Regional Government } \\
\text { of Klungkung }\end{array}$} \\
\hline & & $\begin{array}{l}\text { Desa } \\
\text { Keramas }\end{array}$ & Social tension & \\
\hline & & Desa Tusan & Incendiarism & \\
\hline 3 & $\begin{array}{l}\text { Gianyar } \\
\text { Regency }\end{array}$ & $\begin{array}{l}\text { Desa } \\
\text { Tegalalang }\end{array}$ & Social tension & $\begin{array}{l}\text { Settlement at the police } \\
\text { level }\end{array}$ \\
\hline
\end{tabular}

${ }^{29}$ Interview with Wayan P. Windia, Customary Law Expert at Udayana University, interview on 17 October 2018. 


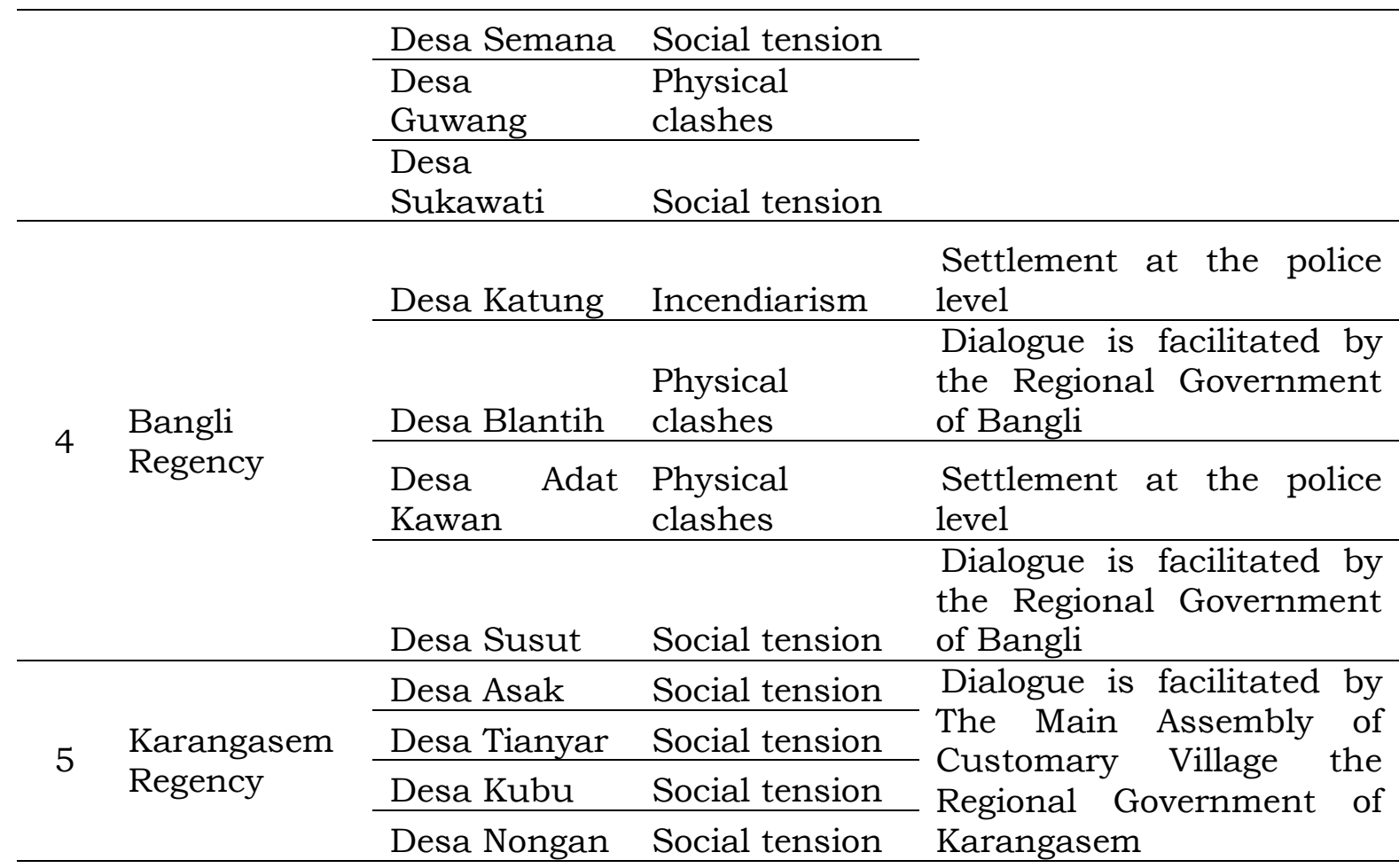

Source: Bali Police Public Relations (2019)

A number of cases that occur can be used as a lesson to learn about the shape, type, and background of the cause. No less important is that stakeholders in the context of customary villages and official administrative villages are able to produce a solution that can restore the calmness, peace and progress to all villages in Bali. The following are some examples of conflicts that occur between traditional villages and official administrative villages

Table 2

Conflict cases between traditional villages and official administrative villages in Bali

\begin{tabular}{|c|c|c|c|}
\hline No & Location & $\begin{array}{l}\text { Conflict } \\
\text { Related Parties }\end{array}$ & Description / Solution \\
\hline 1 & $\begin{array}{l}\text { Bungkulan. } \\
\text { Village, Sawan }\end{array}$ & $\begin{array}{l}\text { customary } \\
\text { villages and } \\
\text { official } \\
\text { administrative } \\
\text { villages }\end{array}$ & $\begin{array}{l}\text { There is currently no meeting } \\
\text { point, because of historical } \\
\text { issues. The location that is still } \\
\text { being debated is in the southern } \\
\text { part of the two neighboring } \\
\text { villages, namely between Dauh } \\
\text { Muduk (Bungkulan Village) and } \\
\text { Banjar Dangin Yeh (Giri Emas } \\
\text { Village). The Bungkulan Village } \\
\text { claimed that the area was part of } \\
\text { the village administration, } \\
\text { because there was an Alit Temple } \\
\text { where most of the pangempon } \\
\text { were the Pakraman Bungkulan } \\
\text { Village manners. }\end{array}$ \\
\hline
\end{tabular}




\begin{tabular}{|c|c|c|c|}
\hline 2 & $\begin{array}{l}\text { Munduk Kunci } \\
\text { official } \\
\text { administrative } \\
\text { villages and } \\
\text { Tegallinggah } \\
\text { Village }\end{array}$ & $\begin{array}{l}\text { customary } \\
\text { villages and } \\
\text { official } \\
\text { administrative } \\
\text { villages }\end{array}$ & $\begin{array}{l}\text { The conflict began with a } \\
\text { commotion carried out by two } \\
\text { young men because of old } \\
\text { revenge, from the Munduk Kunci } \\
\text { Village and Tegallinggah Village, } \\
\text { the commotion caused a dispute } \\
\text { between the villagers concerned. } \\
\text { Sukasada District Police invited } \\
\text { both parties and their parents } \\
\text { witnessed Perbekel Tegalinggah } \\
\text { Village, and Kelian Banjar } \\
\text { Munduk Kunci, local police, and } \\
\text { military personnel in Tegalinggah } \\
\text { Village agreed to reconcile to } \\
\text { resolve the misunderstanding in a } \\
\text { family manner and promised not } \\
\text { to repeat it, above a peace } \\
\text { statement at the Office of } \\
\text { Tegalinggah Village. }\end{array}$ \\
\hline 3 & $\begin{array}{l}\text { Desa } \\
\text { Sumberklampok }\end{array}$ & $\begin{array}{l}\text { customary } \\
\text { villages and } \\
\text { official } \\
\text { administrative } \\
\text { villages }\end{array}$ & $\begin{array}{l}\text { The prolonged land ownership } \\
\text { conflict that occurred in } \\
\text { Sumberklampok Buleleng Village } \\
\text { was finally taken over by the Bali } \\
\text { Provincial Government by creating } \\
\text { a team consisting of Regional } \\
\text { Government bureaucracies, } \\
\text { members of the Regional House of } \\
\text { Represenatives police and military } \\
\text { personnels, District Governments } \\
\text { and related institutions that were } \\
\text { considered important and } \\
\text { competent aimed at to carry out } \\
\text { data collection, measurement, } \\
\text { mapping and resolution of the } \\
\text { problems of the land of ex- } \\
\text { cultivation rights number } 1 \text {, } 2 \\
\text { and } 3 \text { in Sumberklampok Village. }\end{array}$ \\
\hline 4 & Desa Gobleg & $\begin{array}{l}\text { customary } \\
\text { villages and } \\
\text { official } \\
\text { administrative } \\
\text { villages }\end{array}$ & $\begin{array}{l}\text { This is due to factors of } \\
\text { confidence, village history, } \\
\text { population, and related business } \\
\text { or business potential. Mediation } \\
\text { efforts have been carried out by } \\
\text { the government and assigned } \\
\text { each village to show strong } \\
\text { physical evidence. Nevertheless, } \\
\text { the government continues to } \\
\text { strive to resolve village boundaries } \\
\text { in a persuasive manner by } \\
\text { promoting consensus among } \\
\text { community leaders. }\end{array}$ \\
\hline
\end{tabular}

Source: Bali Police Public Relations (2019) 
The causes of conflict and violence can be explained by using the theory of structural conflict. One of the social scientists who develops this theory is Ralf Dahrendorf, known as a conflict sociologist because of his criticism of functional structure considered to ignore conflicts that are inherent parts of people's lives. Dahrendorf proposes the following points: 1) every society always experiences a process of change, and the process of change is a symptom inherent in people's lives; 2) every society always shows the existence of conflict and disagreement (dissensus), social conflict is always present in people's lives; 3) every element of society contributes to the occurrence of disintegration and social change; 4) every society is integrated based on coercion by a number of people for a number of other people. ${ }^{30}$

The above social conflicts and changes stem from the struggle for the rare resources, resulting in uneven distribution of resources. As a result, in people's lives, there are groups of people who are capable of mastering material objects and groups who are unable to master material things. Such conditions in Marxist thought are caused by factors of production ownership, which give rise to the bourgeois class and the proletarian class which have no production factor. Whereas the non Marxist school views that conflict is caused by differences in authority, namely between groups that have authority and groups that do not have authority. In another view, Haryatmoko, states that conflicts will be very easily triggered, especially those related to issues of power and injustice. ${ }^{31}$

Conflicts that occur in society, according to Dahrendorfstem from the existence of differences in the position of authority, in which one party is the dominant group that seeks to maintain the social structure through its legitimate authority and groups that do not have the authority (subjection) trying to make changes to the social conditions seized by the dominant group. ${ }^{32}$ Customary villages and official villages in Bali are faced with the phenomenon of globalization and modernization that have entered the village and the complexity of social problems that are increasingly high, including also dealing with very heterogeneous (multicultural) communities.

Based on the concept of conflict theory as outlined above, customary and socio-economic conflicts that occur in Bali, between individuals, groups, banjar or customary villages and official administrative villages are actually not different from the theory, namely the unequal opportunity in the economic field, and the existence of dominant group dominating other groups and the existence of social change and cultural values shift. In the

\footnotetext{
${ }^{30}$ Ralf Dahrendorf. Konflik dan Konflik dalam Masyarakat Industri. (Jakarta: Rajawali, 1986).

${ }^{31}$ Haryatmoko. Etika (Politik dan Kekuasaan). (Jakarta: Penerbit Buku Kompas, 2003), 65.

32 Ralf Dahrendorf, loc.cit.
} 
dynamics of society which is characterized by the rapid flow of globalization, democracy, science and technology such as the advancement of information and communication technology, have an influence on the desire of the individuals to fulfill their needs faster and even instantly. It causes social change, which affects the shift in cultural values. The sacred value turns profane, the value of togetherness shifts into individualistic, the value of religion changes to economic value such as the seizure of the pelaba pura (temple's belonging in the form of land); people no longer concerned with the village stakes or boundaries that have been set aside because of the economic interests.

Besides, there is the wrong understanding of democracy, that in any realm democracy, people can do everything even do anarchism. It can also be due to the occurrence of cultural lag and shock. The cultural lag is the condition of society called cultural backwardness, namely on one side of certain groups or groups of high educational and work ethic level so that they are economically well-established, while other groups are still classified as marginal because they are unable to adopt progress (one group with ethos of gamblers and other groups working hard and economically). The cultural shock is a condition of shock as a result of not being able to accept new institutions such as competitive, hard work and fast, disciplined, efficient-effective and accountable. As a result, there is little friction that results in emotional action that is very contrary to human and religious values.

One of the thoughts that can used to prevent and even eliminate customary conflicts in Bali is by revitalizing local wisdom that already has adhi-luhung (good) character based on the concept of bebrayan (community life), developing a polite personality in the diversity by always coordinating and integrating through balanced communication between various stakeholders including the administrative village. With a variety of local wisdom concerning various fields of life, it has been proven and tested its reliability for the Balinese people in the face of scouring new values from within and outside the country. Balinese people through village role models are also required to deepen the appreciation of local wisdom, in which wisdom is inseparable from religious philosophy, interpret and apply dynamically in facing the challenges of change while maintaining humanitarian principles so that the threat of disharmony between citizens of customary village and existing structures can be prevented. In addition, future state policies must be able to touch and benefit the lower classes of society in an open, honest and fair manner in accordance with the values of the Pancasila.

Efforts to harmonize village dualism between customary and official administrative villages in Bali are still on small scale. The implementation of activities related to research shows that most of the customary and official 
administrative villages in Bali carry out their respective activities with harmony, respect and mutual cooperation. This is indicated by the results of interviews with customary and official administrative villages administrators in several villages in Bali which stated that so far there had never been a conflict between customary and official administrative villages because they have their respective duties and support each other. In carrying out their respective duties, customary and official administrative villages complement each other in order to harmonize the program, vision, and mission of the village. Just as when customary villages carry out customary or religious activities, the official administrative village provides assistance in the form of funds and others. The customary village will always support and succeed in village official work when implementing work programs that are aimed to increase the village economy. In its implementation between customary and official administrative villages, they are able to show solidarity and cooperation. Therefore, the existence of village dualism in village governance in Bali is not a threat to the harmony of the people in Bali.

\section{Conclusion and Recommendation}

The transformation of local leadership in Bali has been going on for a long time even in the colonial era, the Japanese government, the Old Order, and its peak occurred in the New Order era. After the fall of the New Order, a reformation era emerged that also seemed to bring considerable changes in local leadership in Bali, in which customary villages and other traditional authorities were sufficiently strengthened and given a greater role by supralocal governments, both provincial and regency (district) or city governments. Strengthening the position of customary villages and the role given by the supra-local government have implications for the strong bargaining position of the customary villages in the government as well as the citizens.

The big role of customary villages and the strong bargaining position have a big influence on the occurrence of the negaranisasi process in customary villages. The negaranisasi referred to in this study is the process of taking over a number of state roles, carried out by customary villages in the village community, as well as the customary village process in imitating the state in carrying out its duties. The concrete examples of the take over the process of a number of state's roles is the role of customary villages in maintaining security through pecalang in securing and regulating traffic, controlling settlers, securing party congress activities and including other events. While the phenomenon of customary villages mimicking state authority is building security posts, holding and using pecalang cars for patrols like police, voting systems in determining or changing leaders that are previously done by consensus system. 
The competency of local leaders in both the official and customary village government seems to still be an obstacle in carrying out such heavy tasks. The number of laws and rules governing the village, and must be done by the village, as well as the system and model of financial management with a considerable amount, make the village government difficult to carry out. Meanwhile, the educational level of the village government, both official and customary villages, is still dominated by senior high school and the equivalent education, and even some are still in junior high school and elementary school. Besides, the abilities and skills possessed to carry out the tasks of financial management, village administration, handling various community issues are still far from adequate.

The findings of various factors that cause conflict in villages, both official and customary villages, are on issues of coordination, adaptation to modernization, and various changing behaviors of the community. While the way to handle conflict is still relatively status quo, so many are irrelevant to resolve the issue, some even reach the court level. The limited ability and quality of resources in the village are also factors that cause conflict, as well as inhibiting factors in the process of dealing with conflict issues. A number of approaches that seem relevant for resolving conflicts and have been running now are cultural approaches as well as strong surveillance of citizens up to social isolation in Bali called kasepekang.

To maintain the existence of customary villages in Bali in order to survive, separate regulations are needed that specifically regulate customary villages. However, the arrangement of leadership in customary villages is indeed inseparable from the leadership of the administration of the official administrative village, because the customary villages in Bali are included in the scope of the State administration. In order to develop the customary villages in the future, it is time for them to be managed by human resources who have sufficient capacity to avoid conflicts in relation to the official administrative village. They also need clear funding allocations, both in terms of sources and uses, so that their village management activities become more directed and measurable within the framework of ensuring community welfare.

\section{BIBLIOGRAPHY}

\section{Book}

Ardana, I Gusti Gede. Pemberdayaan Kearifan Lokal Masyarakat Bali dalam Menghadapi Budaya Global Denpasar: Pustaka Tarukan Agung, 2007. Ashsofa, Burhan. Metode Penelitian Hukum, cet ke-3 Jakarta: Rineka Cipta, 2001. 
The Implications of Village Regulation toward the Dualism of Local Leadership Dynamics

I Nyoman Subanda, I Nyoman Budiana and A.A.Ngr Eddy Supriyadinata Gorda

Atmadja, I Dewa Gede. Awig-Awig Desa Adat Suatu Analisis Hukum Tata Negara, Revitalisasi Awig-Awig Desa Adat Denpasar: Fakultas Hukum Universitas Udayana 2005.

Dahrendorf, Ralf. Konflik dan Konflik dalam Masyarakat Industri. Jakarta: Rajawali, 1986.

Gorda, I Gusti Ngurah. Manajemen dan Kepemimpinan Desa Adat di Propinsi Bali. Denpasar: Widya Kriya Gematama, 1999.

Hartono Hadikusumo. Negara Teater Kerajaan-Kerajaan di Bali Abad XlX. Yogyakarta: Yayasan Banteng Budaya, 2000.

Haryatmoko. Etika (Politik dan Kekuasaan). Jakarta: Penerbit Buku Kompas, 2003.

Kartodirja, Sartono (ed). Paper of The Forth Indonesian-Dutch History Conference (Agrarian History) Yogyakarta: Gadjah Mada University Press, 1986.

Nugroho, Riant. Otonomi Daerah: Desentralisasi Tanpa Revolusi; Kajian Dan Kritik Atas Kebijakan Desentralisasi di Indonesia. Jakarta: Elex Media Komputindo, 2004.

Sunggono, B. Hukum dan Kebijaksanaan Publik. Jakarta: Sinar Grafika, 1994.

Surpha, I Wayan. Seputar Desa Pakraman dan adat Bali. Denpasar: Bali Post, 2002.

Widja, Gede. Dualisme Kepemimpinan Lokal pada Desa-Desa Pegunungan di Kabuapaten Buleleng dan Implikasinya dalam Pembangunan Nasional Singaraja: Laporan Penelitian STKIP Singaraja, 1994.

\section{Journal Article}

Arisandi, Fahmi. "Peran Strategis Pemerintah Daerah dalam Mengakui Masyarakat Hukum Adat." Jurnal Surya Keadilan: Jurnal Ilmiah Nasional Terbitan Berkala Fakultas Hukum Universitas Muhammadiyah Bengkulu 2, no. 1 (2018): 271-272.

Mulyanto, "Keberlakuan UU No. 6 Tahun 2014 Tentang Desa di Bali dalam Perspektif Sosiologi Hukum." Mimbar Hukum-Fakultas Hukum Universitas Gadjah Mada 27, no. 3 (2015): 418-431. https://doi.org/10.22146/jmh.15880

Nurjaya, I Nyoman, "Sustainable Cultural Development: The Future Of Balinesse Adat Village Posterior The Enactment Of Law Number 6 Year 2014 Concerning Village", Jurnal Jatiswara, 33, no. 1 (2018): 1-12.

Perbawa, I. "The Implications of Act no. 6 Year 2014 on The Village Existence of Adat Village in Bali1." International Journal of Research in Social Sciences 6, no. 2 (2016): 122-140.

Rauf, Muhammad A. "Politik Hukum Pembentukan Desa Adat Dalam Sistem Pemerintahan di Indonesia." DE LEGA LATA: Jurnal Ilmu Hukum 1, no. 2 (2017): 413-429. https://doi.org/10.30596/dll.v1i2.802

Satrya, I. Ketut Teguh Yudha, et al. "Sinergi Desa Adat fan Desa Dinas Dalam Pengelolaan Aset Desa Untuk Mewujudkan Harmonisasi (Studi Pada Desa Adat Dan Desa Dinas SambangaN)." JIMAT (Jurnal Ilmiah Mahasiswa Akuntansi) Undiksha 7, no. 1 (2017). http:/ /dx.doi.org/10.23887/jimat.v7i1.9376 
Sugiantiningsih, Putu, I. Made Weni, and Tommy Hariyanto. "Effect of Bali Province Regional Regulation Number 4 of 2019 on Pecalang Organizations in Bali." International Journal of Multicultural and Multireligious Understanding 6, no. 3 (2019): 728-734. http://dx.doi.org/10.18415/ijmmu.v6i3.875

Sunu, I Gusti Ketut Arya. "Harmonisasi, Integrasi Desa Pakraman dengan Desa Dinas yang Multietnik dan Multiagama Menghadapi Pergeseran, Pelestarian, dan Konflik di Bali." Jurnal Imu Sosial dan Humaniora 3, no. 2 (2014): 446-458. $\quad$ http://dx.doi.org/10.23887/jishundiksha.v3i2.4469

Suyadnya, I. Wayan. "Self-Identification and Repositioning of the Tengananese in the Discourse of Adat Community in Bali." Masyarakat: Jurnal Sosiologi (2019): 27-51. https://doi.org/10.7454/MJS.v24i1.10183

Vel, Jacqueline AC and Adriaan W. Bedner. "Decentralisation and village governance in Indonesia: the return to the nagari and the 2014 Village Law." The Journal of Legal Pluralism and Unofficial Law 47, no. 3 (2015): 493-507. https://doi.org/10.1080/07329113.2015.1109379

Wardana, Agung, "Debating Spatial Governance in the Pluralistic Institutional and Legal Setting of Bali." The Asia Pacific Journal of Anthropology 16, no. 2 (2015): https://doi.org/10.1080/14442213.2014.997276

Wisnumurti, Anak Agung Gede Oka and I Wayan Rideng. "The Development of Bali Tourism Through Cultural and Local Wisdom of Pakraman Village." Journal of Tourismology 3, no. 2 (2017): 38-43.

Yudiawan, I. Dewa Herman. "Pendapatan Desa Adat: Kontruksi Hukum Pungutan Untuk Mewujudkan Bebas Pungutan Liar." Jurnal Magister Hukum Udayana (Udayana Master Law Journal) 8, no. 2 (2019): 249260. https://doi.org/10.24843/JMHU.2019.v08.i02.p08.

\section{Legal Documents}

The 1945 Constitution of the Republic of Indonesia.

The Law Number 6 of 2014 concerning Village

The Law Number 23 of 2014 concerning Regional Government

The Regional Regulation of the Province of Bali Number 4 of 2019 concerning Customary Villages in Bali 